\title{
薬物療法における注射剂処方への薬学的関与の意義
}

\author{
久保田ひとみ ${ }^{* 1}$, 縄田修- ${ }^{1}$, 杉山 貢 $^{1}$, 岩田政則 ${ }^{2}$ \\ 横浜市立大学附属市民総合医療センター薬斉部 ${ }^{1}$ \\ 日本薬科大学物理薬剂学分野 2
}

\section{Significance of Pharmacist Intervention in Determining Formulas of Injectable Medicines}

\author{
Hitomi Kubota*1, Shuuichi Nawata ${ }^{1}$, Mitsugu Sugiyama ${ }^{1}$ and Masanori Iwata ${ }^{2}$ \\ Department of Pharmacy, Yokohama City University Medical Center ${ }^{1}$ \\ Department of Physical Pharmacy, Nihon Pharmaceutical University ${ }^{2}$
}

$\left[\begin{array}{l}\text { Received September 22, } 2006 \\ \text { A ccepted March 17, } 2007\end{array}\right]$

We investigated the effectiveness of pharmacist interventions in determining formulas of injectable medicines by examining 887 inquiries concerning such medicines made between A pril 2002 and March 2005. The number of inquiries increased after the seasonal rotation of physicians and residents, this showing the importance of providing information and guidance to physicians and residents concerning injectable medicines.

Inquiries concerning dose and interactions among drugs accounted for two-thirds of total number of inquiries, suggesting that it is important for pharmacists to intervene in determining formulas when necessary. The inquiries avoided about $3,240,000$ yen of unnecessary hospital expenditure, and their number decreased annually. These results were achieved through the provision of information to doctors by pharmacists.

Thus pharmacist inquiries concerning formulas of injectable medicines were seen to be effective in increasing patient safety and raising efficiency in hospital management.

Key words — injectable medicine, pharmacist intervention, risk management, hospital management

\section{緒言}

近年 , 病院管理の主な課題は, 患者を中心とした安全 管理と病院経営を考慮した効率的な医療提供といえる。 また，これらの取り組みは全病院的であり，種々の医療 従事者によるチーム医療で行われることが多い，注射剂 による医療事故が多発する昨今，注射剂は，医師の処方 に基づいて薬斉師が調剂したのち患者に投与される .般に, 注射剂 ${ }^{1}$ (は内用剂に比べて薬効が強力かつ速やか であること，高価であることが炎の特徵として挙げられ， その管理は安全管理および病院経営には重要な要素の一 つとなる，炎のため，薬剂師業務における注射剂調剂 は，医薬品適正使用を考慮して行われる．横浜市立大学 附属市民総合医療センター(旧横浜市立大学医学部附属 市民総合医療センター)では, 注射剂調剂にオートアン プルディスペンサー(自動注射剂払出機)を導入した新た
なシステムを構築した . 谷の結果, 本システムはオーダ リングシステムと連動することから省力化を可能とし， 処方内容のチェックと疑義照会に費やす時間か確保され だ). 疑義照会の内容と得られた成果などをデータベー ス化して，業務の検討資料とした．さらに，疑義照会の 内容を解析し，独自に作成した相互作用チェック表，小 児科用簡易投与量チェック表の有用性を確認した4).

本研究では, 薬剂師が注射剂調剂を行う上で, 安全管 理および病院経営管理の両面から処方の疑義照会が重要 であることに注目して, 新たに 1 年間の疑義照会内容を 解析, 検討し, 前報 ${ }^{4)}$ と比較した。

\section{対象と方法}

1. 調査期間とデータ収集

新たに抽出した資料の調査期間は，2004年 4 月から 2005年 3 月までの 12 力月間とした . 疑義照会にあたつ 
ては，独自に作成した相互作用チェック表，小児科用簡 易投与量チェック表および成書4.すをもとに，定時注射剂 処方内容を鑑査した . 電話による疑義照会を実施した 後, 特に多い内容については参考文献を含めた処方変更 依頼書を添付した . 連日の得られた数值は, 記録され毎 月ごとに集計を行い，前報山の一部のデータを加えた 36 カ月について検討した .

\section{2. 調査項目}

入院患者数は平日朝 9 時に当院のオーダリングシステ ムより取得した .また, 注射剂処方せん枚数は薬斉部で 調剂された注射せん枚数を記録した。

実施した疑義照会について，前報慅に従い独自の「プ レアボイド報告書」を作成して产の中から疑義照会日， 診療科, 患者年齢, 性別, 疑義照会内容, 得られた成果 または予想される成果, 軽減された薬剤費を抽出した。 また，患者名や医師名等の個人情報に関わる項目につい ては, 薬阂師が符号化し院内専用のパソコンを用いて処 理した。集積したデータの処理は,「ファイルメーカー Pro」(クラリス(株))を使用した . 得られた数值の統計学 的処理”は，ステューデントのt検定により評価した .

疑義照会内容

疑義照会の内容は，「投与量」，「用法」，「相互作用」， $\ulcorner$ 同種薬併用」, 「保險請求上の問題点」, 「关の他」の 6 項目に分類した .

\section{(1)投与量}

投与量に関わる主な疑義照会は, 投与量が著しく少量 または過量である場合, 同一の処方が重複して入力され た場合，注射剂の処方が1日ごとに入力されるところを 複数日入力された場合, 病棟のストックとして入力され た場合，がん化学療法実施計画書と投与量が一致しない 場合とした。

(2)用法

用法に関わる主な疑義照会は, 投与回数や点滴速度等 の投与に関する指示が矛盾する場合, 溶解 ・希勫方法の 溶解液の選択，投与期間や投与間隔が規定からはずれて いる場合とした .

(3)相互作用

投与薬斉の相互作用を, 薬動力学的相互作用, 物理化 学的相互作用, 光の他の相互作用に分類した . いずれの 相互作用に関する情報は, 薬剂の添付文書や成書)を参 考にした。

(4)EBM (Evidence Based Medicine)に基づかない同種薬 の併用

EBM に基づかない同種薬の併用(同種薬)に関わる主 な疑義照会は，2刘の併用により薬理学的な相加作用や 相乗作用が生じる場合とした。例を挙げると, プロトン ポンプ阻害薬と $\mathrm{H}_{2}$ ブロッカーを同時に使用する場合》や
エビデンスを有せずに同系統の抗生物質を併用する場合 などである .

\section{(5)保険請求上の問題点}

保険請求上の問題点に関わる主な疑義照会は, 主に保 険適用外使用を対象とした . 例を挙げると, 注射剂を他 の投与経路で使用する場合, 高カロリ一輸液用ビタミン 製剂を末梢静脈を介して使用する場合，投与量と製剂規 格の選択が不適当な場合などである .

(6)光の他

弚の他の疑義照会としては, オーダリングシステムの 不具合によりデータが送信されない場合，鑑査した薬㓢 が異なる病棟へ搬送された場合, がん化学療法実施計画 書が提出されていない場合等 ${ }^{1-5}$ の問い合わせ内容に分 類できないものとした .

\section{3. 得られた成果}

疑義照会を行うことで得られた成果を，副作用の回 避, 薬効の減弱の回避, 薬剂費負担の軽減, 弚の他の 4 項目に分類した。記載にあたり，疑義照会による成果は 複数の項目について計測した .

\section{4. 軽減された薬剤費}

疑義照会の実施により，予想される薬剂費の軽減効果 を保険薬価で算出した、調査期間は, 本研究における 2004 年 4 月から 2005 年 3 月までの 1 年間にわたり測定 した。

結果

\section{1. 入院患者数と処方せん枚数}

月ごとの延べ入院患者数と 1日あたりの平均入院患者 数，および注射剂の定期処方せん枚数と1日あたりの注 射剂の定期処方せん枚数を表 1 に示す. 3 年間の 1 日あ たりの平均患者数は $583 \pm 17$ 名(平均 \pm 標準偏差) 最大 值および最小値は，606名(2003年 10 月), 536 名(2002 年 9 月)であった . 同樣に月ごとの1日処方せん枚数の

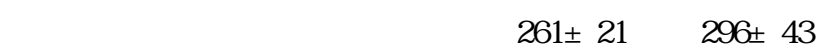

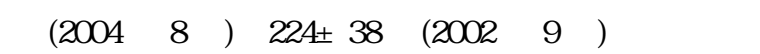

\section{2. 疑義照会件数の経時的変化}

調査期間の 3 年間における疑義照会総件数は 887 件 , 1 力月間の疑義照会件数の最高值は 47 件, 最低值は 13 件であった . また, 1 力の平均疑義照会件数は $25 \pm 8$ 件(平均士 標準偏差)であり, 測定月によって変動するこ とが観察された(図 1).

3. 診療科別疑義照会

主な診療科別の疑義照会件数を表 2 に示す．疑義照会 
表 1. 月別 1日入院患者数, 1 日処方せん枚数および1力月間の疑義照会件数

\begin{tabular}{|c|c|c|c|}
\hline & $\begin{array}{c}\text { 1日入院患者数 } \\
\text { (平均士 標準偏差) }\end{array}$ & $\begin{array}{l}\text { 1日処方せん枚数 } \\
\text { (平均士 標準偏差) }\end{array}$ & $\begin{array}{c}1 \text { 力月間の } \\
\text { 疑義照会件数 }\end{array}$ \\
\hline 2002年 4 月 & $554 \pm 15$ & $238 \pm 36$ & 27 \\
\hline 5 & $541+24$ & $227 \pm 38$ & 29 \\
\hline 6 & $572+20$ & $255 \pm 31$ & 23 \\
\hline 7 & $564 \pm 18$ & $254 \pm 39$ & 13 \\
\hline 8 & $557 \pm 20$ & $258 \pm 35$ & 26 \\
\hline 9 & $536 \pm 26$ & $224 \pm 38$ & 17 \\
\hline 10 & $563 \pm 24$ & $263 \pm 40$ & 30 \\
\hline 11 & $585 \pm 24$ & $256 \pm 33$ & 19 \\
\hline 12 & $576 \pm 28$ & $254 \pm 39$ & 18 \\
\hline 2003 年 1月 & $582+44$ & $284 \pm 56$ & 24 \\
\hline 2 & $599 \pm 18$ & $292+39$ & 22 \\
\hline 3 & $594 \pm 26$ & $283 \pm 40$ & 19 \\
\hline 4 & $576 \pm 22$ & $265 \pm 34$ & 28 \\
\hline 5 & $584 \pm 14$ & $273 \pm 57$ & 18 \\
\hline 6 & $596 \pm 23$ & $292+49$ & 27 \\
\hline 7 & $605 \pm 17$ & $270 \pm 51$ & 26 \\
\hline 8 & $603 \pm 19$ & $259 \pm 48$ & 20 \\
\hline 9 & $579 \pm 23$ & $256 \pm 46$ & 23 \\
\hline 10 & $606 \pm 19$ & $276 \pm 46$ & 47 \\
\hline 11 & $600 \pm 15$ & $254 \pm 47$ & 22 \\
\hline 12 & $592+32$ & $246 \pm 50$ & 38 \\
\hline 2004 年 1月 & $579 \pm 49$ & $265 \pm 55$ & 37 \\
\hline 2 & $602+20$ & $270 \pm 35$ & 40 \\
\hline 3 & $600 \pm 15$ & $282+42$ & 22 \\
\hline 4 & $596 \pm 18$ & $257 \pm 39$ & 39 \\
\hline 5 & $582+19$ & $231+39$ & 27 \\
\hline 6 & $583 \pm 17$ & $253 \pm 33$ & 23 \\
\hline 7 & $589 \pm 20$ & $278 \pm 44$ & 22 \\
\hline 8 & $580 \pm 16$ & $296 \pm 43$ & 25 \\
\hline 9 & $584 \pm 20$ & $264 \pm 41$ & 29 \\
\hline 10 & $590 \pm 19$ & $260 \pm 44$ & 21 \\
\hline 11 & $583 \pm 17$ & $263 \pm 37$ & 25 \\
\hline 12 & $581+28$ & $268 \pm 38$ & 15 \\
\hline 2005 年 1月 & $571+35$ & $263 \pm 42$ & 15 \\
\hline 2 & $602+19$ & $278 \pm 47$ & 18 \\
\hline 3 & $599 \pm 14$ & $284 \pm 42$ & 13 \\
\hline 平均值 & $583 \pm 17$ & $261+21$ & $25 \pm 8$ \\
\hline
\end{tabular}

件数が多い診療科は, 消化器病センター(147 件 , 16.6 $\%) ，$ 臟血管センター(92 件，10.4\%)，血液内科(77 件 , 8.7\%)，小児科(67 件，7.6\%)，難病センター(59件， $6.7 \%)$ となり，これらの診療科の疑義照会件数は全体の 約半数を占めた .
4. 疑義照会内容による分類

調査 3年間における疑義照会内容(投与量, 用法 , 相 互作用，同種薬，保険請求上の問題点，弚の他)と炎の 件数を図 2 に示す . 総件数 887 件のうち，投与量および 相互作用に関する疑義照会は 586 件となり，全体の約 3 分の 2 を占めた . 一方 , 保険請求上の問題点に関する疑 義照会は，99件となり，全体の $11.2 \%$ であった . 


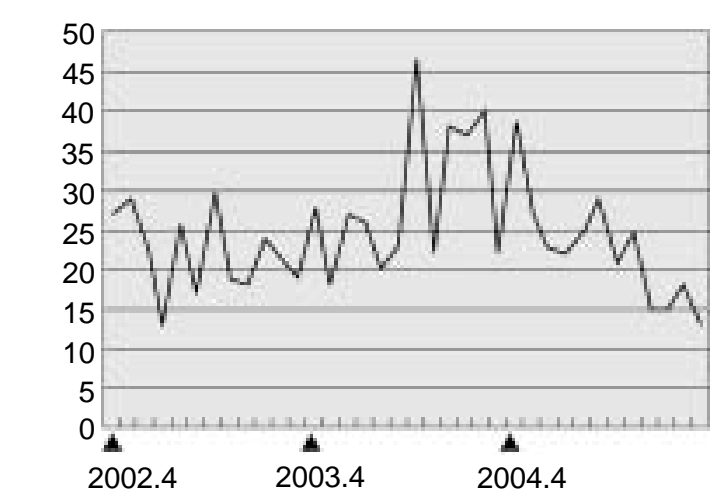

図 1.1 力月間の疑義照会件数の経時的変化

表 2 . 主な診療科別の疑義照会

\begin{tabular}{l|c|c}
\hline \multicolumn{1}{c|}{ 診療科 } & 疑義照会件数 & 割合 $(\%)$ \\
\hline 消化器病センター & 147 & 16.6 \\
心臓血管センター & 92 & 10.4 \\
血液内科 & 77 & 8.7 \\
小児科(PHCU を含む) & 67 & 7.6 \\
難病医療センター & 59 & 6.7 \\
泌尿器・腎移植科 & 55 & 6.2 \\
耳鼻咽喉科 & 52 & 5.9 \\
総合外科 & 42 & 4.7 \\
呼吸器内科 & 42 & 4.7 \\
神経内科 & 39 & 4.4
\end{tabular}

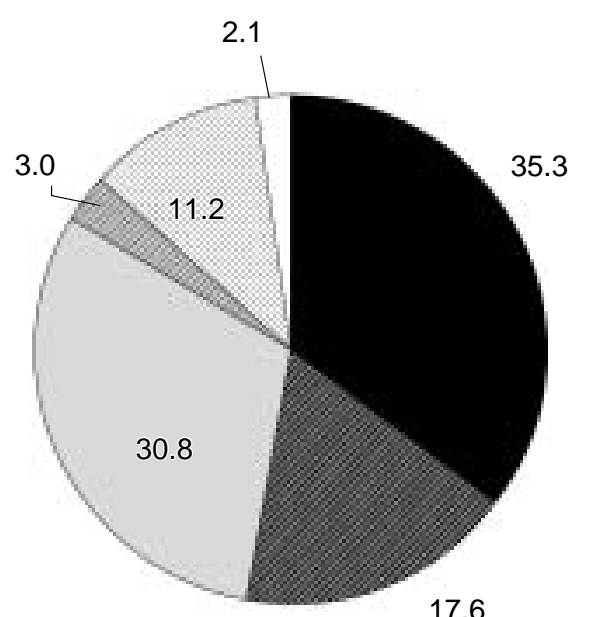

$1:$ 投与量

U/H 2: 用法

3: 相互作用

䝚 $4:$ 同種薬

: 5 : 保険請求

$\square$ 6: 谷の他

調査期間 : 2002 年 4 月 2005年 3 月(総数 887 件)

図 2.3 年間の疑義照会内容による分類と件数

1)投与量

投与量に関する疑義照会件数は 3 年間にわたる調査期 間中で 313 件となり，全体の $35.3 \%$ であった .このう
ち, 同一処方や類似処方などの重複入力が 218 件(69.6 \%)であった . 本事例の中で, 複数の医師による入力も 見受けられ, 弚の3分の 2 を占めた . また , 添付文書上 の投与量を大きく上回るか, または下回るなどの投与量 に関わる処方への疑義照会は 81 件(25.9\%)であつた .い ずれも医師による重複入力が投与量に関する疑義照会の 60〜 70\% を占めた。

2)用法

用法に関する疑義照会件数は，3年間にわたる調査期 間中で156件となり，全体の $17.6 \%$ であった .このう ち，処方せん上の用法とコメントが不一致(指示不一致) である事例が 143 件と大多数を占めた . 疑義照会件数 は, 2003 年度から急激に増加し, 指示不一致が $90 \%$ 以 上を示した(図 3). このほか, 注射剂の溶解・希釈法に 関するものが 12 件，关の他1件であった .

\section{3)相互作用}

相互作用に関する疑義照会は，3年間にわたる調査期 間中で 273 件となり，全体の $30.8 \%$ であった .このう ち物理化学的相互作用に関連するものは 129 件, 薬動力 学的相互作用に関連するものは95件であった. 年度毎 の疑義照会件数の変化では減少する傾向が観察された (図 4).

4)同種薬

同種薬に関する疑義照会は 27 件であり，全体の $3.0 \%$ となった．このうち，同種製剂の併用は14件であり，

ほぼ半数を占めた .

5)保険請求上の問題点

保険請求上の問題点に関する疑義照会は 99 件，光の うち保険適用外使用が 32 件，製剂の規格選択が 63 件で あった. 年度別に关の疑義照会件数をみると，初年度に 比べて, 次年度以降は総件数が減少した(図 5). 複数単 位の同一製剂が存在する場合，弚の効率的な規格の選択

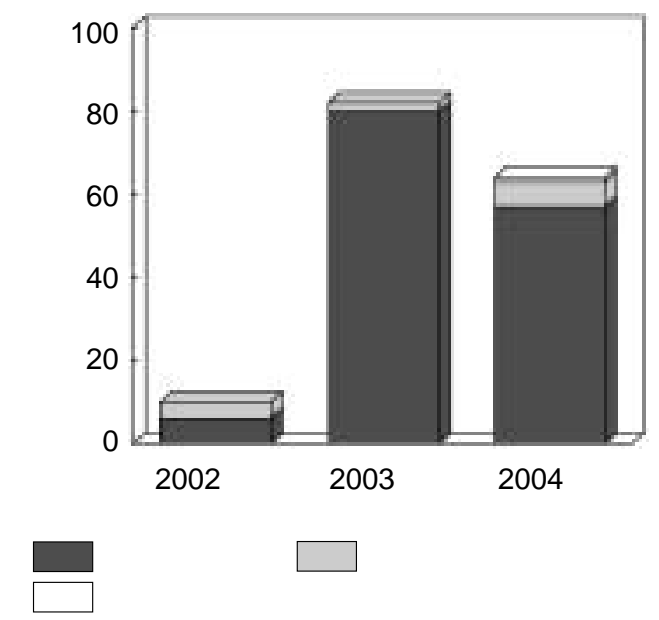

図 3. 用法に関する疑義照会の内訳 


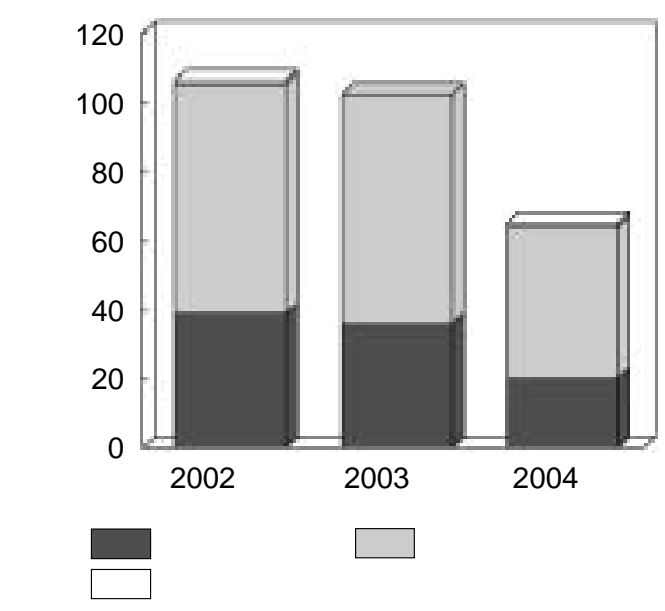

図 4. 相互作用に関する疑義照会の内訳

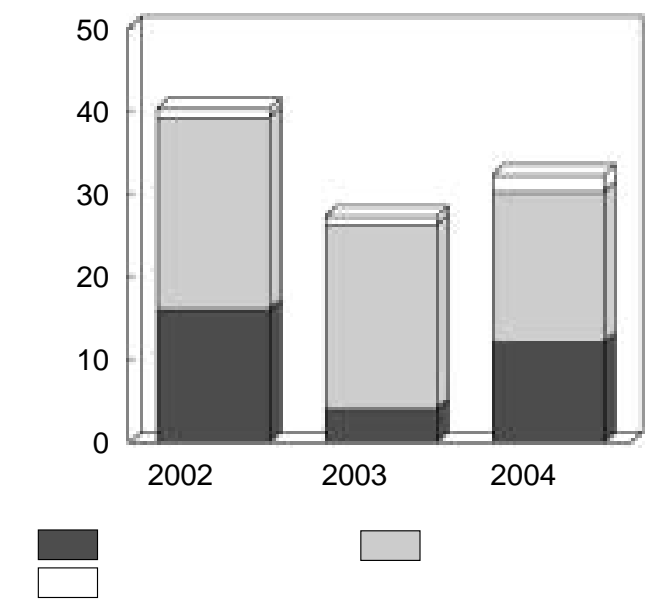

図 5 . 保険請求上の問題に関する疑義照会の内訳

に関する疑義照会が半数以上を示した .

6)光の他

乥の他の疑義照会は 19 件, 光のうちオーダリングシ ステムに関するものが 8 件, 弚の他が11件となった . オーダリングシステムに関する疑義照会の対象は，医師 のみならず医療情報担当者にも及んだ。昨今，オーダリ ングシステムに関するものに加えて , がん化学療法にお けるプロトコール管理に関わる業務が増加傾向にあり， 疑義照会の内容も变化している．

\section{5. 安全管理面からみた成果}

疑義照会によって得られた成果の 3 年間にわたる延べ 総数は, 927 件であった . また, 種類別成果の件数(1力 月あたりの平均土標準偏差)は，「副作用の回避」583(16

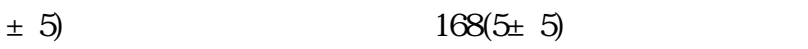

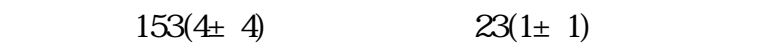

6. 病院経営面からみた成果

調査期間とした 2004 年度における注射剂の病院経営
に影響を与えると思われる疑義照会件数は，272件とな り，疑義照会により損失を免れた金額は，約 324 万円で あった . 保険請求時における病院負担の回避額を診療科 別にみると，血液内科 201 万円，難病医療センター 19 万円，整形外科 15 万円の順であった . また，疑義照会 1件あたりの金額は, 血液内科 7.7 万円，難病医療セン ター 2.3 万円，整形外科 2.9 万円であった .

\section{7. 主な疑義照会例の推移}

主な疑義照会 4例について, 年度ごとに光の件数の変 化を検討した(図 6).いずれも年度を重ねることによ り，疑義照会件数が減少する傾向を示した。

\section{考察}

1. 疑義照会件数への入院患者数および処方せん枚数の 影響

月別の平均 1 日入院患者数および定時処方せん枚数の 值を単回帰式により予測を試みたところ，いずれの相関 係数は 0.281 および 0.141 となった .これより各值は経 時的な増減傾向はなく，新たな調査結果と差はないもの と判断した . 同樣に1力月間の疑義照会件数についても 同樣な結果が得られた .さらに，この2 要因を説明変数 として疑義照会件数を重回帰分析で予測したところ，得 られた式の相関性は低い値を示した $\left(\mathrm{R}^{2}=0.095\right)$.これら の結果より，本研究にあたり，疑義照会件数に対する入 院患者数および定時注射剂処方せん枚数の影響はないと 判断した .

3月および 4月が退職, 新入の職員変動の時期である ことから疑義照会件数について注目した . 3 年間におけ

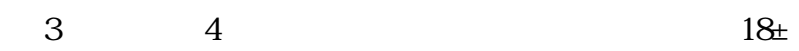
5 件および $31 \pm 7$ 件となった . ステューデントのt検定

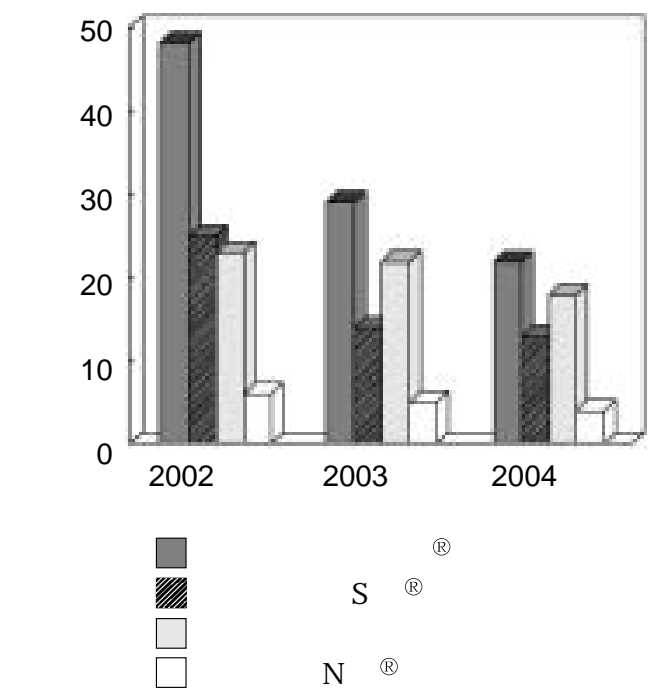

図 6. 主な疑義照会例の推移 
により比較したところ，疑義照会件数は危険率 10\% 以 下で有意差がみられた . わが国において，4月は年度始 めのために研修医や他の病院勤務医師の異動時期にあた ることが多い，本結果より，当院が大学病院という特性 上，医療スタッフの異動時期か影響したものと推察され る .これらを解決するには, 異動の時期に合わせて , 注 射処方の入力に関する研修の機会を設けることが必要で あるといえる .

\section{2. 診療科別疑義照会件数}

本結果は, 前報 ${ }^{4}$ の結果と類似した . 上位 5 診療科の 疑義照会件数が全体の約半数を占めたことから，これら の診療科を重点的な対応か効果的となる.今回，疑義照 会を受けた医師について調査した。薬斉師から複数回に わたり疑義照会を受けた医師は, 10 回以上が 12 名存在 し，光の最高値は 17 回であった . 本結果から，医師， 薬斉師間のより効果的で密なる情報交換の必要性が求め られると判断した .

\section{3. 疑義照会の内容による解析}

疑義照会の内容からみると，投与量および相互作用に 関する疑義照会が 586 件となり，全体の約 3 分の 2 を占 めたことは，薬斉師による処方鑑査と疑義照会が患者に 対する有害事象の発生が未然に回避され，薬物療法にお ける安全管理面から有用であると考える，一方，保険請 求上の問題点に関する疑義照会は, 99 件(11.2\%)であっ た . 病院経営を考慮した疑義照会もまた今後, さらに推 し進めるべき課題であるといえる . 投与量に関する疑義 照会件数は，3年間にわたる調査期間中で313件となった .

医師による重複入力が投与量に関する疑義照会の 60〜70\% を占めた . 本事例の中で, 複数の医師による 入力も見受けられたことから，オーダリングシステムの 改善が必要であると考える . 一方, わずかであるが, が ん化学療法における投与量の疑義照会も2004年度は 5 件であった．2005年度からほぼ全科を対象としたこと から, 件数の増加が予想されるため, 兴の対応の必要性 が示唆される。

指示不一致に関する疑義照会においては，医師の才ー ダー時の入カミスが多くみられた . 例えば，処方上では 1 回投与であるが, 実際は病棟ストックから使用し 2 回 分投与されている可能性である. 当院ではオーダーによ り会計を行っているため，保険請求漏れにつながる．処 方せん鑑査と疑義照会の実施により，誤った投与法の回 避のみならず保険請求の漏れを防ぎ，ひいては病院経営 の改善にもつながるものと考える .

相互作用に関する疑義照会では, 各年度にわたり物理 化学的相互作用に関する疑義照会が全体の半数以上を占 めた .これは, 薬阂師が従来から物理化学を基盤とした
薬学的業務を展開してきたことに由来するものと考え る.物理化学的相互作用は, 反応によって力価が低下す ることにより期待される薬効は得られない(8) . また , 病 棟において沈殿や変色をおこした薬阂は廃棄される場合 が多い．これは，病院経営にとって大きな負担となる． 仮に，患者に投与された場合には，フィルターの目詰ま りによる点滴速度の低下と薬物血中濃度の変化が危惧さ れる.一方, 薬動力学的相互作用は, 生体に対する影響 が大きく，時として重篤な問題を引き起こすことが知ら れている.今後も，注射剂に関する相互作用や配合変化 に関する最新の情報を取得して医薬品情報部門との連携 と対応が必要と考える。

同種薬併用の主な事例として, 高カロリ一輸液処方に おける 2 種類の総合ビタミン剂, $\mathrm{H}_{2}$ ブロッカーとプロ トンポンプ阻害薬であった . また , エビデンスに基づか ない複数の抗生物質の併用は 13 件とほぼ半数であっ た.特に塩酸バンコマイシン点滴静注用 ${ }^{\circledR} 0.5 \mathrm{~g}($ 塩野義製 薬(株))とハベカシン注射液 ${ }^{\circledR} 100 \mathrm{mg}$ (明治製菓(株))の併用 は, 而性菌の出現や保険請求など多くの問題が存在す る. 抗生物質の適正使用に関しては, 院内の感染対策委 員会との連携も考慮すべきと考える .

保険請求に関する疑義照会では, いずれの年度でも製 斉規格の選択に関するものが半数以上を示した .これら の問い合わせは，保険診療を行う病院にとって基本的か つ大切な疑義照会である. 適応があっても製剂規格が不 適当のため保険請求か認められない場合もあり，高額な 抗がん斉や頻用される薬斉に関しては特に，処方する医 師への周知が必要と考える．また，注射剂を外用剂とし て使用する場合についても光の対象となると考える．

\section{4. 病院経営からみた疑義照会}

病院経営に関わる疑義照会を，保険薬価に換算して検 討した 新たな調査期間である 2004 年度の回避金額は， 約 324 万円であった . 回避金額を診療科別に比較したと ころ,血液内科に対する総疑義照会件数は 40 件であり， 兴の内病院経営に関する疑義照会は 26 件(65\%)であっ た . 血液内科関連の值が高額となった原因として，抗悪 性腫瘍薬やこれに伴う副作用改善目的の注射剂を適用す る事例か推察される，一方, 整形外科や難病医療センター では高額の特殊な薬阂や抗生物質の適用が考えられる。 これらの結果より，薬阂師による注射斉処方への疑義照 会は, 病院経営の面からも有用であることが示された .

\section{5. 主な疑義照会と产の効果}

主な疑義照会 4例について，年度ごとに关の件数の変 化を検討したところ，いずれも年度を重ねることによ り，疑義照会件数が減少する傾向を示した。例 1 は, 微 量元素類のコロイド粒子が分散したエレメンミック注 ${ }^{\circledR}$ 
(味の素(株))と物理化学的相互作用 ${ }^{9}$ が予測される薬剂と の混合例であり，多くが可溶化斉のコンドロイチン硫酸 ナトリウムと反応して沈殿を生じることから，疑義照会 とともに情報提供文書を添付した . 例 2 は, ホスミシン $\mathrm{S}$ 静注用 ${ }^{\circledR} 2 \mathrm{~g}$ (明治製菓(株))の溶解液の選択である．本剂 は , ナトリウムを $14.5 \mathrm{mEq} / \mathrm{g}$ 含有することから , 添付 文書では生理食塩液ではなく $5 \%$ ブドウ糖液が指示され ている．ちなみに，生理食塩液 $100 \mathrm{~mL}$ は , $14.4 \mathrm{mEq} の$ ナトリウムを含有する . 疑義照会とともに必要に応じて 文書による情報提供を行った．例 3 は，製剂規格の選択 である.製剂の規格が複数ある場合，保険薬価，利便性， 安全性などを考慮して選択する必要がある．例 4 は，脂 溶性ビタミン製剂であるケイツー $\mathrm{N}$ 静注用 ${ }^{\circledR} 10 \mathrm{mg}$ (エー ザイ(株))と物理化学的相互作用 ${ }^{10)}$ が予想される薬剂との 混合例である．主薬は界面活性剂であるダイズレシチン の添加により可溶化されているが , 化学反応により, 分 離，レシチン集合体の凝集などが予想される．これらの 現象を説明する情報提供文書も同時に添付した . 兴の結 果，年度ごとに減少傾向が観察された．例 1 は 2002年 度が 48 件であったが，2004年度は 22 件となり約半数 以下となった . 同樣に , 他の例 2 , 例 3 , 例 4 についても 減少する傾向が観察された．疑義照会による処方の改善 と件数の減少効果は, 電話による問い合わせのみならず 電話と文書による情報提供が重要であることを示唆して いる。

一方, 重複入力の照会例に関しては初年度 67 件 , 2 年目 82 件，3年目 65 件となり，減少傾向は観察されな かった . 重複入力が放置された場合，患者に不要な負担 を強いることにもなり，保険請求時における病院の負担 も少なくない，今後は，個々の薬剂師と医師との電話に よる問い合わせだけでなく，システム的な対応など病院 全体の課題として検討される必要であると考える .

米国では，薬物療法における有害事象の予防と医療費 抑制の報告は多く，Classen ら ${ }^{11}$ は，4年間にわたる Case control study で薬物有害事象をおこした 1580 名の患者 と 2 万名以上のコントロール患者を比較して , 障害の種 類, 起因する費用, 入院日数などを比較して钅の防止が 重要であることを示した .
最近，国の施策として薬学教育 6 年制に伴う薬斉師業 務の変革が行われることとなった . 病院における薬阂師 業務もまた，安全管理と病院経営での機会損失効果の回 避への貢献が求められつつある . 注射剂調剂のみならず 患者や医療スタッフが求める業務展開が必要と考える.

\section{引用文献}

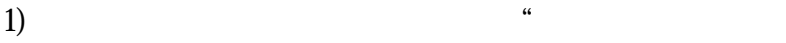
剂学”，丸善，東京，1998，pp. 64-65.

2) 佐藤秀明, 注射薬調剂の考え方, 月刊薬事, 43,221224 (2001).

3) M. Iwata, Y. Takahashi, T. Honda, S. Kaneda, K. Kojima, R. Y oshihara, R. Mio, K. Sakai, K. Y amamoto, $Y$. Machida, An A utomatic Ampoule Dispensing Sys tem Improved Injection Dispensing, System Improved Injection Dispensing, Jpn. J. Pharm. Health Care Sci., 29, 470-475 (2003).

4) 岩田政則, 久保田ひとみ, 佐々木玩也, 縄田修一, 注射剂調剂における疑義照会の解析，医療薬学 $\mathbf{3 1}$, 707-713 (2005).

5) 山口県病院薬剂師会編, “注射薬調剂鑑査マニュア ル”、エルゼビア・サイエンス ,東京 ,2002pp. 1-672.

6) 柳井久江 “"4 Stepsエクセル統計” 星雲社, 東京, 2004, pp. 80-83.

7) 岩田政則, 縄田修一, 高橋由里, 月見里薰, 吉原隆 一，酒井君子，三尾良一，山本勝義，注射剂適正使 用のための調剂業務システム $-\mathrm{H}_{2}$ 受容体遮断薬, プロトンポンプ阻害薬— , 医療薬学 , 29, 593-598 (2003).

8) 岩田政則,島村春巳, 矢沢洋一, 平野裕美, 長田進, 城武昇一，IVH製剂に配合されたビタミン類の安 定性，横浜医学，42,129-133 (1991).

9) 山岡佳子, 中島康雄，微量元素製剂混注高カロリー 輸液剂にみられる退色現象の検討，日本病院薬剂師 会杂隹誌, 33, 457-460 (1997).

10) 千堂年昭, 大槻集司, 大坪健司, 青山敏信, 沢田勝, 中野賢二, 栢野正則, 脂溶性ビタミン $\mathrm{K}_{2}$ 注射剂 イツー N 注」のフィルター通過に関する検討, 新 薬と臨床，42，1778-1787 (1993).

11) D.C. Classen, S.L. Pestonik, R.S. Evans, Adverse drug events in hospitalized patients, Excess length of stay, extra costs, and attributable mortality, JAMA, 277, 301306 (1997). 